\title{
Beyond Ambiguity and Ambivalence: Rethinking the Tools of Critique
}

\author{
Elizabeth S. Anker (Cornell University)
}

\begin{abstract}
:
This essay analyzes the central architecture of critique. It argues that, across the humanities, critique has followed a uniform methodology, wherein qualities like ambiguity, ambivalence, uncertainty, contradiction, and paradox have represented the main tools of not only critique and unmasking but also disclosure and transformation. Within teaching philosophy, critique has thus done more than to politicize the classroom; it has also ingrained an equation between pedagogy and therapeutic witnessing or confessionalism. For many, qualities like ambiguity and uncertainty have furthermore been imagined to bear distinctly 'ethical' fruits. This essay questions these staples of pedagogical theory, in particular the redemptive faith that paradox and contradiction will prove inherently critical and/or progressive. It therefore historicizes the architecture of critique, submitting that among other things the contemporary political climate challenges unbridled faith in those qualities. And it instead promotes values like trust, integrity, clarity, and noncontradiction as the goals of a postcritical education.
\end{abstract}

Keywords:

ambivalence; critique; ethics; integrity; pedagogy

As critique transformed higher education, the last decades of the 20th Century also witnessed a politicization of the classroom. That revolution of the classroom into a space imagined to carry preeminent sociopolitical importance was predicated on a number of assumptions. It certainly repurposed longstanding accounts of the liberal arts as a training ground for democracy and civic participation. In addition, it converted the classroom into a consciousnessraising theater, orchestrated by a pedagogy aimed at successive dramas of exposure (Sedgwick, 2003). Across classrooms within the university and beyond, the particularized stories especially of society's downtrodden have been expected to generate not only elevated but cosmically momentous insights, whether into the anatomy of power or systemic oppression or imperialism and its histories.

Critique thereby created new rationales for the unrivaled merits of the humanities. However, many of the warrants underlying the ensuing conflation of pedagogy and politics beg for re-examination. Turbocharged, the classroom came to be heralded as a privileged arena for unmasking bias and oppression, envisioned as a microcosm of the political. But while largescale structural wrongs have been that exercise's ostensible referents, the classroom's dynamics have demanded localized, intimately blameworthy targets, even encouraging forms of scapegoating. At once, such pedagogy aimed at the expansion of both students' and (as we will see) the instructor's consciousness has evinced an enormous faith in symbolics - or a conviction that purely symbolic gains will catalyze real-world sociopolitical and economic consequences, near automatically. Conceived as a process of awakening both internally and outwardly directed, it is within pedagogy that the oppositional mindset of critique has accordingly been accompanied, perhaps unexpectedly, by a kind of therapeutics. Yet of even greater perplexity, and notwithstanding those psycho-emotional dynamics, academic proponents of critique have often been severely allergic to re-channeling its dissident, contrarian energies into an affirmative, productive, normatively aimed praxis: into concrete, tangible political platforms or goals. Like humanistic inquiry overall, pedagogy has therefore suffered from a surfeit of critique: a prioritization of critique at the expense of other activities and agendas.

In turn, some have questioned the "anti-normativity” of theory (see Wiegman \& Wilson, 2015). Relatedly, there are concerns to be raised about humanists' peculiarly 'antiinstrumentalist' conceptions of not only pedagogy but also political agency and action. Rita Felski has further complained that "a hypercritical style has crowded our alternative forms of intellectual life” (Felski, 2015, p. 10). But another set of explanations for these liabilities lies less with critique per se than with its central and abiding architecture: with the dominant methodology and tools enlisted to effectuate critical inquiry and edification, whether in scholarship, the classroom, or beyond.

Uniformly central to critique has been a methodology erected on faith in the epistemic yield of qualities like difficulty, complexity, indeterminacy, ambivalence, paradox, ambiguity, and contradiction. Those qualities 
have been enlisted to conduct manifold types of intellectual-pedagogical labor. Most immediately, properties like 'contradiction' and 'discontinuity' have represented the main apparatus of critique: of power, capitalism, modernity, history, oppression, and more. Hence, Frederic Jameson promotes "the notion of contradiction [as] central to any Marxist cultural analysis” (Jameson, 1981, p. 80). Enjoining specifically Marxist literary critics, Jameson insists: "the interpretive mission of a properly structural causality will [...] find its privileged content in the rifts and discontinuities within the work" (Jameson, 1981, p. 56). In a notably similar vein does Michel Foucault analogously charge revisionist historians with such a mandate: to "fragment[] what was thought unified," "introduce[e] discontinuity into our very being," and demonstrate history to be "an unstable assemblage of faults, fissures, and heterogeneous layers" (Foucault, 1984, p. 82, 86). For thinkers like Jameson and Foucault, the excavation of these sites of discontinuity and contradiction is a necessary preliminary step to critique. And just as theorists like Jameson define ideology as a system for masking capitalism's contradictions, so, too, does genealogy presume that "hegemonic power necessarily suppresses difference in favor of unity [and] abhors ambiguity” (Asad, 1993, p. 17). Such conviction in the critical potency of ambiguity, discontinuity, and analogous qualities has been a calling card of the humanities under the regime of theory.

Within the classroom, those qualities have been imagined to effectuate even more: to do more than merely pilot the activities of critique and suspicion. In addition, a matrix of such properties (paradox, ambiguity, difficulty, complexity, indeterminacy, and more) have been pedagogical mainstays precisely because they are enlisted to perform a multitude of functions - and often interchangeably. On the one hand, a certain cult of difficulty has encouraged an emphasis on negation and even destruction. In such vein, Peter Brooks advocates a "negative dialectics" as the crux of a humanities education (Brooks, 2014, para. 7). As Brooks inveighs, “[f]ar from teaching virtue, we in the humanities advocate immersion in the destructive element” (Brooks, 2014, para. 9). Or, as Terry Eagleton puts it: "All emancipatory theory [...] has built into it a kind of self-destructive device, and moves under the sign of irony” (Eagleton, 1990, p. 33).

But on the other hand, those same qualities championed for their "destructive elements" have been celebrated as transformative, if not redemptive - and here, too, according to diverse logics. A few seminal statements of such thinking can shed light on these protean energies. Within bell hooks's 1994 Teaching to Transgress: Education as the Practice of Freedom, an appeal to transgression encodes not only oppositional critique but also an almost countercultural soul-searching and confessional bearing witness, both to one's own complicity and to larger realities of persecution (see also Brooks, 2000). In an illustration of the frequent knitting together of those divergent commitments, Teaching to Transgress reads as a manifesto for "rethinking," “deconstruction," “antagonism,” and the need to repudiate "accepted boundaries" (hooks, 1994, p. 29, 31, 7). However for hooks, such a "radical pedagogy" simultaneously unfolds through "excitement," "flexibility," and "spontaneous shifts in direction" - or an experimental freedom and play. Even more, hooks underscores the experiential flavor of such an instructional style, advocating a classroom capable of arousing "the passion of experience” (hooks, 1994, p. 90)

Other ingredients of an educational philosophy like hooks's have also been broadly representative. hooks furthermore extols the (auto)biographical status of the content or subject matter germane to a pedagogy of transgression. As she argues regarding such first-hand learning (hooks, 1994, p. 90), it is the instructor's task to foster classroom discussions wherein "everyone's presence is acknowledged" and "[s]tudents [are] seen in their particularity as individuals" (hooks, 1994, p. 7-8). Especially telling, hooks even characterizes her own pedagogy as such an instance of "testimony" and "bearing witness" - a witnessing inextricably enacted within hooks' scholarship and writing (hooks, 1994, p. 11). Teaching, therapy, consciousness-raising, and confession thus become one-and-the same project. Yet it is the sensibility that ultimately emerges from such a classroom convinced of its status as a transgressive space that invites scrutiny. As hooks explains, the components of her vision for the classroom are above all routes to grasping the "particular knowledge that comes from suffering," including its splitting or rupture of the victim's selfhood (hooks, 1994, p. 91). What is at stake in such splitting? First and foremost, hooks's quest for intimate access to suffering emanates from attunement to "complexity." As Teaching to Transgress clarifies: "This complexity of experience can rarely be voiced and named from a distance. It is a privileged location” (hooks, 1994, pp. 90-91).

Gloria Andzaldúa’s 1987 Borderlands/La Frontera offers another statement of this pedagogical spirit that took hold across humanities classrooms along with theory during the 1980s and 1990s. Frequently, that ethos was condensed in distinctive vocabularies - such as, for Andzaldúa, a grammar of "hybridity” (Andzaldúa, 2012, p. 99). In Borderlands/La Frontera, hybridity (along with Andzaldúa's other shorthands for that term) most visibly comments on "identity," and especially ethnic belonging. Activating the biological associations of the "mestiza consciousness” of the borderland, Andzaldúa explains:

At the confluence of two or more genetic streams, with chromosomes constantly 'crossing over,' this mixture of races, rather than resulting in an inferior being, 
provides hybrid progeny, a mutable, more malleable species with a rich gene pool. (Andzaldúa, 2012, p. 99)

Like so many others, Andzaldúa's discourse of hybridity thereby captures a process through which historical stigma of oppression can furnish elevated insight and awareness.

While a framework for converting the pain of exclusion into redemptive (self-) understanding, Andzaldúa's appeals to mixture and crossing above all derive from a romance of ambiguity. Underlying Andzaldúa's reasoning is the crucial expectation that encounters with contradiction and ambivalence will inaugurate superior ways of knowing. Andzaldúa delineates these links:

The new mestiza copes by developing a tolerance for contradictions, a tolerance for ambiguity. ... She has a plural personality, she operates in a pluralistic mode ... Not only does she sustain contradictions, she turns the ambivalence into something else. (Andzaldúa, 2012, p. 102)

We could certainly note that Andzaldúa promotes a modality of critique grounded in symptomatic reading - or the ability "to see the deep structure below the surface" (Andzaldúa, 2012, p. 60). But further illustrative is how her (no doubt dated) tribute to tolerance and pluralism is dramatized via her writing's genre and style: what Andzaldúa refers to as her own writing's "pluralistic mode” (Andzaldúa, 2012, p. 101). While enacting such "mixture" by blending not only Spanish with English but also almost journalistic meditations with theory, precisely this generic eclecticism has been a signature of the critiquedriven humanities classroom (Andzaldúa, 2012, p. 99). In one sense, it is Andzaldúa's commitment to methodological hybridization that breeds a pedagogy fully coordinated by acts of confessionalism (from teacher and student alike). Yet the educational principles that arise are further noteworthy, among other things for being widely echoed. Much as for hooks, it is an ambiguity of style meshed with content that comes to be acclaimed as inherently salvific. "Ambivalence" not only becomes transformative but is valorized as an independent good: as the vehicle capable of ushering in "something else."

There are many invaluable roots to this thinking that overtook the humanities classroom under the banner of critique. W. E. B. Du Bois gives us certain important origins of that mode of thought, crystallized in his influential notion of "double consciousness." Analogously for Du Bois, the experience of psychic "rupture" (hooks) and "ambivalence" (Andzaldúa) wrought by racial oppression produces within the victim "unreconciled strivings" and "warring ideals" (Du Bois, 1903/1997, p. 38). Yet far from wholly negative, that bequest of a mixed or divided consciousness is something Du Bois ultimately theorizes as "at once a deprivation [...] and a gift (an endowment of 'second-sight' that seems to allow a deeper or redoubled comprehension of the complexities of 'this American world')" (Edwards, 2009, p. xiv). It is clearly a Du Boisian sense of hybridized or pluralistic selfhood that Andzaldúa harnesses when she extols "la facultad" of the mestiza for transmuting "intense pain" into "continual creative motion” (Andzaldúa, 2012, p. 60).

Similarly, it is hard to mistake the influence of trauma studies on such a pedagogy convinced that "testimony" and "bearing witness" will offer failsafe learning exercises (hooks, 1994, p. 11). Pioneers of trauma theory like Shoshana Felman and Cathy Caruth have consistently heralded the pedagogical profit of encounters with trauma. In fact, Felman recounts the circumstances that turned one of her graduate seminars into an "uncanny pedagogical experience as my own 'life-testimony", in a "story of how I myself became a witness to the shock communicated by the subject-matter" (Felman, 1991, p. 19).

For some, these eye-opening and creative fruits of experiential encounters with complexity and ambivalence have been understood to reap explicitly ethical rewards. In other common thinking, properties like difficulty and ambivalence have been trumpeted for possessing innately just ramifications - both within the relative sanctuary of the classroom and on a planetary, cross-cultural scale. To probe one brief example of such arguments, a 2013 CNN Op-Ed by the literary critic James Dawes spells out the usual reasoning supporting this equation between difficulty and ethics, including the logic allowing that nexus to be neatly globalized. In that Op-Ed, Dawes's basic goal is to account for the cognitive deficits that permit the perpetration of mass atrocity, exemplified in the growth of ISIS. However, that assessment of ISIS motivates sweeping conclusions about not only the psychology of the perpetrator but also those faculties geared to prevent or counteract cruelty and harm. As Dawes surmises, perpetrators are trained "to think that the world is painted in black and white, not shades of gray." In a familiar move, Dawes characterizes abusers of human rights as captive to a worldview reduced to either-or, friend-enemy, pureimpure, Manichean and binaristic patterns of thinking and analysis (Dawes, 2013, para. 7). Like so many theorists today, Dawes thereby attributes the origins of power, injustice, and oppression to an inability to tolerate qualities like indeterminacy and ambivalence.

But that diagnosis of atrocity simultaneously embeds a strikingly straightforward cure. Indeed, the CNN "story highlights" reflect that tidiness, compressed into a soundbite: "The same steps used for creating monsters can show how to stop atrocities" (Dawes, 2013, n.p.). While not lacking a certain wisdom, a deceptive symmetry here connects scourge and therapy, as the germs of evil are perfectly mirrored in the remedy advanced by Dawes. 
Prominently among Dawes's items of advice for "parents of young boys" is therefore the following admonition:

[T]each him that the world's problems aren't as simple as us-versus-them, good-versus-evil. Teach him that there aren't easy solutions to complex problems. Teach him to tolerate, without fear and anxiety, life's difficult ambiguity and uncertainty. (Dawes, 2013, para. 13)

To be sure, much is accurate about Dawes's widely subscribed to diagnosis of radical evil, and not only history but also contemporary politics are replete with evidence corroborating it. But arguably too much hangs on that nowrecognizable cocktail of complexity and ambiguity. Even more, that statement is followed by another appeal that has been pro forma within the theory-enamored humanities: an appeal to otherness and alterity. The final punchline of Dawes's essay gives voice to such a mantra, in the essay's words, "to seek out 'the other"” and "to see the world through the other's eyes” (Dawes, 2013, para. 14). Shorthand for a deconstructive ethics, the same imperatives governing close reading are imagined to adjudicate matters of justice and ethics on a cross-cultural scale, as the humanities classroom and international human rights tribunals are subsumed within a single problematic.

Importantly, Dawes does accompany this appeal to ambiguity and alterity with other factors that he presents as equally crucial to an education designed to ward off atrocity. Nevertheless, the ability to abridge such reasoning so succinctly should give us pause, on a number of grounds. Because is it really true that respect for complexity will always, invariably trump evil? Are “ambiguity and uncertainty” (Dawes, 2013, para. 13) inherently just, otheroriented qualities? Even if one accepts that tolerance for moral complexity is a necessary ingredient of an ethical sensibility, is such awareness in-and-of-itself a guarantee of principled decision-making or action? In short, it makes a lot more sense to embed complexity within a network of other, equally invaluable intellectual resources, the proportions of which will shift according to context and circumstance. Whereas awareness like ambivalence may provide a normative compass helpfully steering just-ethical choice in certain cases, in others insistence on totalizing indeterminacy will be the deepest problem.

The post-truth, post-facts climate of our current geopolitical moment is replete with examples that should alert us to the dangers of a religion of ambivalence and uncertainty. Too often today, a surplus of moral ambiguity can seem to pose the gravest threat to democracy. Relatedly, an excess appetite for ambiguity can appear to offer the most apt diagnosis of a perpetrator's avoidances and hang-ups: a mentality perfectly tailored to excuse individual violations of norms like decency, kindness, and integrity. In the 21st century, radical evil more accurately breeds and capitalizes on snowballing conditions of public ambivalence and doubt - opportunistically maneuvering the very properties long championed as the backbone not only of critique but also of sociopolitical and cultural consciousness-raising.

This is also to say that, in contemporary political discourse, cries of ambiguity and complexity often operate as mercenary weapons. And as a diversionary tactic, brandishing epistemic ambivalence is prone to outright condone and even encourage cruelty and injustice. While sandbagging the assertions of one's opponents, persistent calls of indeterminacy have progressively derailed standard norms governing civil, respectful public debate - and quite seamlessly so. There is hence a certain irony that the very qualities long hallowed as the lifeblood not only of critique or radical democracy but also of a politicized pedagogy can seem increasingly liable to backfire. Bruno Latour ventures such an observation regarding critique in general, famously asking whether critique has "run out of steam" (Latour, 2004). But is not Latour's observation more appropriately directed at critique's central architecture and equipment? Is not blind faith in the saving graces of indeterminacy, complexity, and ambivalence what looks increasingly myopic - and therefore a central impetus for a postcritical education?

Along with a changed political environment, teachers today encounter a very different student body than they did in the decades when theory came of age. Students today are already well-versed in a public culture of ambiguity and ambivalence, and they have learned to master such an ethos' rhetorical and other performative niceties. On the one hand, the discovery of chronic, thorough-going indeterminacy is nothing new or shocking to them. Whereas insights regarding the relativism of meaning, the constructivist subject, and the contradictions of oppression that is fully structural may have been eye-opening if not shocking one or two generations ago, students today have internalized these recognitions long before arriving in the academy - or even in high school. They have already absorbed the very sorts of insights humanists exalt as intrinsically dissident and radical, finding them neither alarming nor emboldening. Which is to say that, today, the tools of critique represent the new normal: the contemporary status quo.

Moreover, many students have learned to expertly parrot the codes and conventions of critique as an intellectual-pedagogical style, although frequently by paying mere lip service to those pieties. For instance, the norms of the confessional classroom can appear all too easy to maneuver. Students have become highly adept at enacting both hyper-cognizance of and a personal apologetics for the landmines of complicity - all the while, deftly sidestepping those moral hazards. Skilled at divulging sites of incurable contradiction, they are simultaneously nonplussed by a world comprised of double binds. In turn, it is not surprising that students have been 
acclimated to the onus to broadcast their own implicatedness, including to pantomime displays of penance. However, is such an ability not itself a marker of today's elite? Who has the luxury to revel in ambiguity and uncertainty, versus be subjected to brute conditions of survival? And who gets to perform ambivalence, whereas for whom will cloaking one's actions in a mantle of difficulty and indecision be outright dangerous? Clearly, not all students have been groomed by an education sufficiently elite as to instill within them these edicts of high theory. As a badge of savoir-faire, the song-and-dance of complexity can therefore appear its own gateway to power, or the lingua franca that allows one to interface with global circuits of privilege in the $21^{\text {st }}$ Century.

No doubt, statements of contrition within the classroom are often sincere and even heartfelt, just as the motives underlying those gestures can be salutary. But anything that is pro forma risks becoming trite and trivializing. To return full circle, it is furthermore not so evident that the symbolics of the politicized classroom will undergo transplant and grow, taking root and thriving within the real world. If anything, the romance of complexity and its alleged superiority can seem to incite the opposite impulses to retreat and to self-enclosure. Not incidentally, critics have often promoted such styles of reasoning and discourse for exactly such reasons, out of belief in the natural resistance of paradoxes to cooptation-whether to mass propagation or to being repackaged in terms of cognizable, concrete, stable content or goals (for example, see Gabel \& Kennedy, 1984).

This is furthermore because, when complexity and ambiguity are the end-all-be-all, they will embargo a range of countervailing qualities and ambitions. Along with faith in the edifying profit of complexity and ambivalence will invariably come a studied wariness regarding what those qualities are imagined to cancel and to interdict: ideals like clarity, transparency, stability, certitude, confidence, intelligibility, immediacy, and more. Whereas ambiguity is expected to awaken a radicalized consciousness, those contrasting values have been blamed for deadening thought, reinforcing the status quo, buttressing power, and anesthetizing the masses into docile subjects.

This all raises the question of whether, less than dispensing with critique per se, a postcritical educational philosophy must refashion its architecture: must reevaluate criticism's methodological scaffolding, and especially its dependence on a heady mix of complexity, indeterminacy, ambivalence, difficulty and more. I've tried to offer a few reasons why this architecture of critique should worry us. While relinquishing its familiar methodological arsenal, a postcritical pedagogy might simultaneously set out to recover intellectual resources and agendas too long written off and disfavored.
What are those goals? Among many options, let me conclude by proposing three. First, there is little question that the crisis in global democracy has been fanned be an erosion of trust - in civic actors, public institutions, the media, the ordinary channels of political participation, and competing factions of the citizenry. Despotism today actively exploits that trust deficit, provoking doubt and suspicion in order to rationalize malfeasance and wrong. This opportunism problematizes the usual expectation that critique and its habituated tools will provide effective, viable counter-strategies. When an overdose of public suspicion is the problem, will throwing more ambiguity into the mix truly serve to quell or offset such a syndrome? Is it realistic to expect that answering doubt with still more doubt will restore popular trust in either civic reason or democratic process?

In turn, one horizon of a postcritical pedagogy lies precisely with the re-cultivation of trust. This is not to say that certain aspects of sociopolitical life will cease to require dispute and dissensus. However, the activity of critique on its own will create a kind of vacuum. There is a complex story to be told about how the anti-normativity of theory has prohibited the type of evaluative analysis that might differentiate sociopolitical and other projects worthy of endorsement from those rightly necessitating opposition. But the added point is that trust - whether in politics or in daily life - also requires a willingness to embrace and to affirm. It requires taking seriously achievements worthy of veneration, singling out the diverse factors that add up to meaningful progress. If we cannot profess those positive things we cherish, how can pedagogy help to regenerate trust in democracy as a mode of collective belonging - and thereby to safeguard its continued existence?

These are largescale matters, but I'd like to suggest that they must begin with the building blocks of pedagogy in the ordinary classroom. For many of us, the ability to trust an institution, statement, or phenomenon stems from perceptions of certitude and clarity. Yet once again, the architecture of critique has trained us to regard qualities like lucidity and transparency as not only a deceptive mirage but a betrayal of the critical mandate both to debunk and to illuminate. Yet perhaps the task of pedagogy is not only to sing the virtues of the recondite and elusive but also to tarry with expressions of meaning that are credible, uncomplicated, and intelligible? Without fail, the scene of reading in the average humanities classroom has gravitated toward sites of contradiction, mystery, hiddenness and ambivalence, training students to read against the grain of the archive or the text. But what if interpretation also devotes itself to moments of clarity and purpose, pursuing those encounters as equally pregnant with meaning (and meaning involving something other than the contradictions presumed to lurk below the surface)? Why is it a fait accompli that instances of lucidity and coherence will be exposed a smokescreen? In order to defend things like 
medicine and science and statistics and truth against the tyranny of the assault on facts, we need to begin by welcoming assertions of clarity and veracity within the classroom.

Far from last, political talk of late can seem preoccupied with the notion of integrity. Another potentially lofty ideal, I could certainly pause to enumerate the many reasons such a prospect has long excited critics' ire and derision. But integrity is another value that our day-to-day reading and interpretive practices are well suited to model, rendering the classroom a superb space for adjudicating integrity and its varying intimations. While the word integrity can suggest moral uprightness, it is also defined as 'the state of being whole and undivided.' So insofar as integrity represents the exact kind of normative threshold inviting critical recuperation, what would it mean to read for hints of integrity - whether of experience, form, selfhood, politics, or knowing? Whereas critics have assigned preeminent meaning to the frictions and fissures (like the subject) riddling a text, what insights might be gained from instead granting interpretive authority to signs of noncontradiction? What if noncontradiction is less a ruse of power than the very sort of evaluative metric necessary to identify and decry power's contemporary abuses? Even more, if the recovery of trust in the integrity of civic reason is something we care about, should such a project not take hold within the classroom? Precisely by investigating the integrity of judgment and experience can a postcritical pedagogy become a laboratory for rebuilding democracy in the shadow of the unprecedented challenges looming over the 21st Century.

\section{References}

Andzaldúa, G. (2012). Borderlands/La frontera: The new mestiza (4 ${ }^{\text {th }}$ ed.). Aunt Lute Books.

Asad, T. (1993). Genealogies of religion: Discipline and reasons of power in Christianity and Islam. The Johns Hopkins University Press.

Brooks, P. (2000). Troubling confessions: Speaking guilt in law and literature. The University of Chicago Press.

Brooks, P. (2014, December 15). Misunderstanding the humanities. Chronicle. https://www.chronicle.com/article/misunderstanding-the-humanities/

Dawes, J. (2013, May 16). Why a man eats another man’s heart. CNN. http://www.cnn.com/2013/05/15/opinion/dawes-syriavideo/.

Du Bois, W. E. B. (1903/1997). The souls of black folk. Bedford Books.

Eagleton, T. (1990). The significance of theory. Blackwell.

Edwards, B. H. (2009). Introduction. In W. E. B. Du Bois, The souls of black folk. Oxford University Press.

Felman, S. (1991). Education and crisis, or the vicissitudes of teaching, American Imago, 48(1), 13-73.

Felski, R. (2015). The limits of critique. The University of Chicago Press.

Foucault, M. (1984). Nietzsche, genealogy, history. In P. Rabinow (Ed.), The Foucault reader (pp. 76-100). Pantheon.

Gabel, P., \& Kennedy, D. (1984). Roll over Beethoven. Stanford Law Review, 36(1), 1-55.

hooks, B. (1994). Teaching to transgress: Education as the practice of freedom. Routledge.

Jameson, F. (1981). The political unconscious. Cornell University Press.

Latour, B. (2004). Why has critique run out of steam? From matters of fact to matters of concern. Critical Inquiry, 30(2), 225-248.

Sedgwick, E. K. (2003). Touching feeling: Affect, pedagogy, performativity. Duke University Press.

Wiegman, R., \& Wilson, E. A. (2015). Queer theory without antinormativity. differences: A Journal of Feminist Cultural Studies, 26(1).

\section{Recommended Citation}

Anker, E. S. (2020). Beyond ambiguity and ambivalence: Rethinking the tools of critique. On Education. Journal for Research and Debate, 3(9). https://doi.org/10.17899/on_ed.2020.9.7 
About the Author

Elizabeth S. Anker teaches in the English Department and Law School at Cornell University. Her books include Fictions of Dignity: Embodying Human Rights in World Literature (Cornell 2012) and the edited collections Critique and Postcritique (with Rita Felski, Duke 2017) and New Directions in Law and Literature (with Bernadette Meyler, Oxford 2017). She recently co-edited a 2018 special issue of diacritics titled The Novel and the Lyric, and she also edits the book series Corpus Juris: The Humanities in Politics and Law (with Cornell University Press). She is currently writing two books, On Paradox: The Claims of Theory and Our Constitutional Metaphors: Law, Culture, and the Management of Crisis. 